\title{
An association of Orf virus infection among sheep and goats with herd health programme in Terengganu state, eastern region of the peninsular Malaysia
}

Jamilu Abubakar Bala ${ }^{1,2^{*}}$, Krishnan Nair Balakrishnan¹, Ashwaq Ahmed Abdullah ${ }^{3,4}$, Lawan Adamu ${ }^{5}$, Muhammad Syaafii bin Noorzahari ${ }^{1}$, Lau Kah May ${ }^{1}$, Hassana Kyari Mangga ${ }^{1,6}$, Mohd Termizi Ghazali $^{7}$, Ramlan Bin Mohamed ${ }^{8}$, Abd Wahid Haron ${ }^{5}$, Mustapha Mohamed Noordin ${ }^{1}$ and Mohd Azmi Mohd Lila ${ }^{1 *}$ (D)

\begin{abstract}
Background: Orf virus causes a scabby skin lesions which decreases productivity in small ruminants. The unknown status of this disease in the eastern region of Peninsular Malaysia warrants a study to determine sero-prevalence of orf with regards to farmers' compliance level towards the Herd Health Program (HHP) programme.

Results: Out of 504 animals, 115 were positive for Orf-virus antibodies. An overall prevalence rate of $22.8 \%$ indicated a high prevalence of orf disease in this region. It was observed that 25.1\% (92/367) of goats were positive and 16.8\% (23/137) of sheep sero-converted for Orf virus antibody. Several factors were measured for their possible association with prevalence of Orf virus infection. The prevalence was higher in LY farm, JC breed, kid and female animals, and in the presence of disease lesion. Chi-square analysis showed a significant association of three risk factors which are species, age and sex of the animals $(P<0.05)$. Notwithstanding, all other variables showed no significant difference $(P>0.05)$. Farms surveyed usually practised intensive management system, keeping animals in the shade at all time, due to limited availability of suitable land as a free-range grazing area. An interview with small holder farmers revealed a lack of awareness of the main goals of herd health programme. An overall compliance level of $42.7 \%$ was observed for all HHP parameters. Among the 14 main components of HHP modules, animal identification had recorded highest compliance level (84.62\%) while milking management recorded the least compliance (-82.69\%). That explained why there was a high sporadic prevalence of Orf infection in this region.
\end{abstract}

Conclusion: Good herd health supervision is a rehearsal target to prevent an outbreak and the spread of diseases thus reduces economic losses among farmers. Therefore, a good herd health programme should be in place, in order to prevent and control disease transmission as well as to improve herd immunity.

Keywords: Orf virus, Prevalence, Antibody, Risk factors, Herd-health programme

\footnotetext{
*Correspondence: jabala.mls@buk.edu.ng; jamiluwudil@yahoo.com;

azmi@upm.edu.my; azmilila@gmail.com

${ }^{1}$ Virology Unit, Department of Pathology and Microbiology, Faculty of

Veterinary Medicine, Universiti Putra Malaysia, 43400 Serdang, Selangor,

Malaysia

Full list of author information is available at the end of the article
}

(c) The Author(s). 2019 Open Access This article is distributed under the terms of the Creative Commons Attribution 4.0 International License (http://creativecommons.org/licenses/by/4.0/), which permits unrestricted use, distribution, and reproduction in any medium, provided you give appropriate credit to the original author(s) and the source, provide a link to the Creative Commons license, and indicate if changes were made. The Creative Commons Public Domain Dedication waiver (http://creativecommons.org/publicdomain/zero/1.0/) applies to the data made available in this article, unless otherwise stated. 


\section{Background}

Small ruminants have important contributions to human kind and sustainability in terms of their meat, milk, and other ornamental products including biological products for studies of diabetes and insulin production [1-4]. However, several diseases such as contagious ecthyma and pneumonic mannheimiasis present a serious challenge and also affects the productive capacities and benefits of these animal species [5]. Contagious ecthyma is a skin disease caused by Orf virus which is otherwise called sore mouth or infectious labial dermatitis. The virus belongs to the family Poxviridae and genus parapoxvirus which is made up of linear double stranded DNA particles [6]. Several species of animals are susceptible to the infection including sheep, goats, dogs, cattle, camels, some wild animal species and human [7, 8]. Nonetheless, contagious ecthyma is considered primarily a disease affecting goat and sheep population worldwide $[9,10]$. The disease is also a very important zoonotic viral infection associated with painful non systemic proliferative lesions $[11,12]$. Rarely, long standing infections can become complicated by secondary bacterial infection that may extend to internal organs [13]. Transmission occurs by direct contact with an infected animal and/or with contaminated fomites that contain orf virus. Traditionally, the virus will enter the skin through cuts or abrasions and establish the infection. The skin lesions develop and progress in multiple stages ranging from skin reddening (erythema), macule, papule, vesicle, pustule, scab and scar $[14,15]$. Contagious ecthyma usually resolves spontaneously, however in severe cases due to secondary infections or delayed nursing intervention, the economic impact is significant due to deaths and wasting. Similarly, majority of human infections are localized and heal spontaneously without much complications; however, immunocompromised patients can develop large, poorly healed lesions.

The best method for diagnosis of Orf virus infection is culture of the virus on susceptible cell lines [16-18] but this is mostly characterized as laborious and timeconsuming [17]. Moreso, molecular detection using specific Orf virus has been developed, but such assays are unlikely to be useful for herd screening [19]. Enzyme LinkedImmunorsorbent Assat (ELISA) method can be sensitive and inexpensive for field application in the detection of Orf viruses from large number of animal population.

At present some commercial vaccines can control this disease however, anecdotal epizootics of a persistent generalized form of the infection has been reported among goats vaccinated with the first generation orf vaccine prepared for sheep [20]. Similarly, outbreaks of more virulent contagious ecthyma has also been reported among goats vaccinated with the goat-derived contagious ecthyma vaccine [21]. Furthermore, these vaccines have been reported to be associated drawbacks including the inability to produce effective and desirable protection of the vaccinated animals, as well as persistent virus shedding into the environment which poses an increased risk to other susceptible animals [22]. Therefore, vaccination against Orf virus is only recommended in endemic areas [15]. The urgent need to develop an effective vaccine against contagious ecthyma is borne out of its economic importance to especially rural farmers as well as its zoonotic potentials particularly among animal handlers.

Many outbreaks of contagious ecthyma disease in different part of the world including but not limited to Africa, Middle East, Europe, North America and most of the Asean countries including Malaysia [7, 22, 23] thus it has have become a major concern due to the huge economic losses. According to Onyango et al. [24] the estimated national costs of orf disease in the British sheep industry based could reach up to a staggering $£ 10$ million. Moreover, livestock rearing is ranked the highest practice among other agricultural sub-sectors worldwide particularly in Asian regions including Malaysia. A report by the Malaysian Agricultural analysis and Development Institute (MARDI) revealed that small ruminants are among the most popular livestock farming practiced in Malaysia and it is estimated to be 280 times more than the poultry industry. However, this promising industry is being challenged by the menace of infectious diseases including contagious ecthyma which has resulted in a huge financial loss in the country [25]. A recent works conducted by Sadiq et al., [9], Jesse et al., [26] and Bala et al., [27] have elucidated on the prevalence of Orf in the state of Selangor, Malaysia which poses an alarming prevalence high prevalence. However, adequate information on Orf outbreak is lacking on eastern region of Peninsular Malaysia thus, the associated risk factors including the impact on sheep and goat husbandry practices is still obscure. The present study was conducted to determine the seroprevalence of Orf virus in Terengganu state. In our knowledge, this has given the idea that serves as the first documented report on the prevalence of contagious ecthyma in this region. Moreover, this study have further elucidated on the farmers' level of compliance with established herd health programme. A well thoughtful of the current epidemiological situation of Contagious ecthyma infection in the state of Terengganu and Herd health management would allow the establishment of improved disease control program that would benefit small holder farmers.

\section{Results}

All the 13 farms surveyed have consented and responded to the questionnaire. A total of 504 blood samples were collected from sheep and goats. 


\section{Serological assay}

Out of the 504 animals sampled, one hundred and fifteen (115) were positive for orf virus antibody based on the ELISA assay. This indicated an overall score of $22.8 \%$ among the animals sampled across the 13 farms selected. Goat population had the highest percentage (25.1\%) of sero-conversion compared to sheep with $16.8 \%$ positive results. The finding is statistically significant with $P$-value of less than 0.05 (Table 1 ).

\section{Cross-reactivity, sensitivity and specificity of ELISA assay}

There is no cross-reactivity observed upon testing with other related viruses including bluetongue virus (BTV) and Schemallenburg virus (SBV) positive sera samples obtained from sero-converted infected animals. Both BTV and SBV postive control sera produced an optical density (O.D) value below the cut-off reading. Noteworthy, based on the sensitivity (Se) and specificity (Sp) obtained from ROC-curve analaysis determined using MedCalc sortware, the ELISA presented an Se and Sp of approximately 95.2 and $97.8 \%$ respectively showed by the area under the curve (AUC).

\section{Rate of sero-conversion according to sample farms}

Table 2 depicted level of antibody titre for orf virus in relation to sampling location. The highest seroconversion rate was observed in farm LY (60\%), followed by farm LZ (41.7\%) and the least was evident in farm LM (12\%). The association among farms and prevalence rate of orf virus infection is not significant Chi square $\left(\left(\mathrm{X}^{2}\right)=17.889 ; P=0.1191\right)$.

\section{Rate of sero-conversion according to breeds of animals}

Table 3 depicted rate of sero-conversion for orf virus in relation to breeds of animals. The highest rate was recorded among Jamnapari cross (JC) breed (50\%), followed by Saanen breed (27.6\%) and the least was found among Boer (BO) and Toggenburg (TO) both had $0.0 \%$. The association amongst the farms and prevalence rate of orf virus infection is not significant $\left(X^{2}=17.093\right.$; $P=0.0723)$.

\section{Rate of sero-conversion based on risk factors}

The highest prevalence of orf disease was found among kids of less than 3-months old. All of them were sero-
Table 2 Sero-converted animals according to sample farms

\begin{tabular}{lllllll}
\hline Farm & $\begin{array}{l}\text { Total } \\
\text { sample (n) }\end{array}$ & Negative & Positive & $\begin{array}{l}\text { Sero-conversion } \\
\text { rate (\%) }\end{array}$ & \multicolumn{2}{c}{$\begin{array}{l}\text { 95\% Confidence } \\
\text { interval }\end{array}$} \\
\cline { 6 - 8 } & & & & & Lower & Upper \\
\hline AB & 49 & 39 & 10 & 20.4 & 0.1148 & 0.3364 \\
BF & 35 & 28 & 7 & 20.0 & 0.1004 & 0.3589 \\
LB & 11 & 9 & 2 & 18.2 & 0.0514 & 0.477 \\
LH & 19 & 14 & 5 & 26.32 & 0.1181 & 0.488 \\
LI & 105 & 85 & 20 & 19.1 & 0.1268 & 0.276 \\
LM & 25 & 22 & 3 & 12.0 & 0.0417 & 0.2996 \\
LN & 22 & 14 & 8 & 36.4 & 0.1973 & 0.5704 \\
LS & 17 & 12 & 5 & 29.4 & 0.1328 & 0.5313 \\
LW & 33 & 25 & 8 & 24.2 & 0.1283 & 0.4102 \\
LY & 5 & 2 & 3 & 60.0 & 0.2307 & 0.8824 \\
LZ & 12 & 7 & 5 & 41.7 & 0.1933 & 0.6805 \\
MF & 83 & 57 & 26 & 31.3 & 0.2237 & 0.4195 \\
PT & 88 & 75 & 13 & 14.8 & 0.0884 & 0.2365 \\
Total & 504 & 389 & 115 & 22.8 & 0.1937 & 0.2668 \\
\hline
\end{tabular}

converted. This was followed by $29.7 \%$ in animals of older than 4 years. Interestingly, animals aged 4-9 months have the lowest positive rate (20\%). The association amongst the various age groups and rate of sero-coversion for orf virus infection is significant $\left(X^{2}=8.163\right.$; $P=0.0428)$. The association amongst the various age groups and rate of sero-conversion antibody for orf virus infection is significant $\left(\mathrm{X}^{2}=8.163 ; P=0.0428\right)$.

From a total of 174 male sheep and goats that were examined, 31 (17.8\%) were sero-converted for Orf virus. However, out of a total of 330 female sheep and goats examined, 84 (25.5\%) were sero-converted for the virus (Table 4). The association amongst the gender of animals and the rate of sero-conversion for orf virus is significant $\left(\mathrm{X}^{2}=3.886 ; P=0.0487\right)$.

The rate of sero-conversion among animals with clinical orf disease (66.7\%) was higher than the animal's who are devoid of obvious clinical manifestations of orf (22.6\%). The association between the occurrence of clinical orf disease and sero-conversion is not significant $\left(\mathrm{X}^{2}=2.629 ; P=0.1049\right)$.

Among 504 sheep and goats sampled, none of the farms were observed to practice Orf vaccination to their animals. Therefore, no association exists between the

Table 1 Overall result of ELISA according to animal species

\begin{tabular}{llllllll}
\hline Species & Total sample $(\mathrm{n})$ & Negative & Positive & Sero-conversion rate (\%) & \multicolumn{3}{c}{ 95\% Confidence interval } \\
\cline { 7 - 8 } & & & & & Lower & Upper \\
\hline Goat & 367 & 275 & 92 & 25.1 & 0.2091 & 0.2975 \\
Sheep & 137 & 114 & 23 & 16.8 & 0.1146 & 0.2393 \\
Total & 504 & 389 & 115 & 22.8 & 0.1937 & 0.2679 \\
\hline
\end{tabular}


Table 3 Sero-converted animals according to breeds

\begin{tabular}{|c|c|c|c|c|c|c|}
\hline \multirow[t]{2}{*}{ Breed } & \multirow[t]{2}{*}{$\begin{array}{l}\text { Total } \\
\text { sample (n) }\end{array}$} & \multirow[t]{2}{*}{ Negative } & \multirow[t]{2}{*}{ Positive } & \multirow[t]{2}{*}{$\begin{array}{l}\text { Sero-conversion } \\
\text { rate }(\%)\end{array}$} & \multicolumn{2}{|c|}{$\begin{array}{l}95 \% \text { Confidence } \\
\text { interval }\end{array}$} \\
\hline & & & & & Lower & Upper \\
\hline $\mathrm{BB}$ & 88 & 75 & 13 & 14.8 & 0.0884 & 0.2365 \\
\hline$B C$ & 46 & 37 & 9 & 19.6 & 0.1065 & 0.3318 \\
\hline $\mathrm{BO}$ & 4 & 4 & 0 & 0 & 0.0000 & 0.4899 \\
\hline DO & 49 & 39 & 10 & 20.4 & 0.1148 & 0.3364 \\
\hline$J C$ & 2 & 1 & 1 & 50.0 & 0.0945 & 0.9055 \\
\hline$J P$ & 98 & 79 & 19 & 19.39 & 0.1278 & 0.2831 \\
\hline KC & 3 & 3 & 0 & 0 & 0.0000 & 0.5615 \\
\hline KJ & 56 & 35 & 21 & 37.5 & 0.2601 & 0.5059 \\
\hline SA & 105 & 76 & 29 & 27.6 & 0.1997 & 0.3685 \\
\hline SC & 52 & 39 & 13 & 25 & 0.1523 & 0.3821 \\
\hline TO & 1 & 1 & 0 & 0 & 0.0000 & 0.7935 \\
\hline Total & 504 & 389 & 115 & 22.8 & 0.1937 & 0.2668 \\
\hline
\end{tabular}

$B B$ Barbados Blackbelly, $B C$ Boer Cross, $B O$ Boer, DO Doper, JC Jamnapari Cross, JP Jamnapari, KC Katjang Cross, KJ Kajang, SA Saanen, SC Saanen Cross, TO Toggenburg

vaccination history and the sero-conversion rate of Orf disease amongst all the farms as the potential risk factor.

\section{Result for HHP farmer's compliance level}

All farmers raised either pure breed or crossbred Boer, Boer cross, Katjang, Katjan cross, Jamnapari, Jamnapari cross, Saanen, Saanen cross, Barbados Blackbelly, Doper, and Toggenburg breeds. Majority of the farms raise their sheep and goat primarily for meat, however, rearing for dairy purposes have been considered a convenient alternative. Animals were reared in a simple shed with lowcost housing materials. Animals were fed with cutgrasses and feed pellets under a standard ration. Farmers employed a strong rubber made feeding utensils for feeding. Drinking water were provided ad-libitum. Trees for shading and grasses for animal feed were grown in the pasture areas nearby. Figure 1 shows the type of housing, the type of feed and feeding system generally observed in most farms.

Figure 2 depicted the general body condition of some of the animals surveyed. Both sheep goats were continuously kept under this housing confinement with limited access to grazing and pasture areas. The overall compliance level based on the total 93 questions answered by the farmers is $42.7 \%$ while an overall non-compliance level observed was $57.7 \%$. Table 5 showed the farms level of compliance and non-compliance to HHP's modules, Farms AB, PT and LM showed the highest compliance level with 15, 14 and $14 \%$ respectively while, farms LY, LS, LZ, and LN recorded the highest non-compliance level of 12, 11, 11, and $11 \%$ respectively to HHP modules.

Table 6 presented the summary of the overall farm compliance level to HHP modules as analyzed by nominal regression analysis. Farms LS, PT, AB, LM, LZ, LY and LN showed strong compliance $(p<0.0001)$ for HHP. However, the effect of HHP modules on farms BF, MF,

Table 4 Sero-converted animals according to other risk factors

\begin{tabular}{|c|c|c|c|c|c|c|}
\hline \multirow[t]{2}{*}{ Variable } & \multirow{2}{*}{$\begin{array}{l}\text { Total } \\
\text { sample } \\
\text { (n) }\end{array}$} & \multirow[t]{2}{*}{ Negative } & \multirow[t]{2}{*}{ Positive } & \multirow{2}{*}{$\begin{array}{l}\text { Sero- } \\
\text { conversion } \\
\text { rate }(\%)\end{array}$} & \multicolumn{2}{|c|}{ 95\% Confidence interval } \\
\hline & & & & & Upper & Lower \\
\hline \multicolumn{7}{|l|}{ Age Months } \\
\hline Kid (0-3) & 2 & 0 & 2 & 100 & 0.3424 & 1.0000 \\
\hline Young (4-9) & 105 & 84 & 21 & 20 & 0.1347 & 0.2865 \\
\hline Adult (10-36) & 333 & 260 & 73 & 21.9 & 0.1781 & 0.2667 \\
\hline Old (37-72) & 64 & 45 & 19 & 29.7 & 0.1991 & 0.4177 \\
\hline \multicolumn{7}{|l|}{ Gender } \\
\hline Female & 330 & 246 & 84 & 25.5 & 0.2105 & 0.3041 \\
\hline Male & 174 & 143 & 31 & 17.8 & 0.1285 & 0.2418 \\
\hline \multicolumn{7}{|l|}{ Orf Lesion } \\
\hline Absent & 501 & 388 & 113 & 22.6 & 0.1911 & 0.2641 \\
\hline Present & 3 & 1 & 2 & 66.7 & 0.2077 & 0.9385 \\
\hline \multicolumn{7}{|l|}{ History of orf } \\
\hline No & 504 & 389 & 115 & 22.82 & 0.1937 & 0.2668 \\
\hline Yes & 0 & 0 & 0 & 0 & 0.0000 & 0.0000 \\
\hline \multicolumn{7}{|c|}{ Vaccine against orf } \\
\hline No & 504 & 389 & 115 & 22.82 & 0.1937 & 0.2668 \\
\hline Yes & 0 & 0 & 0 & 0 & 0.0000 & 0.0000 \\
\hline
\end{tabular}



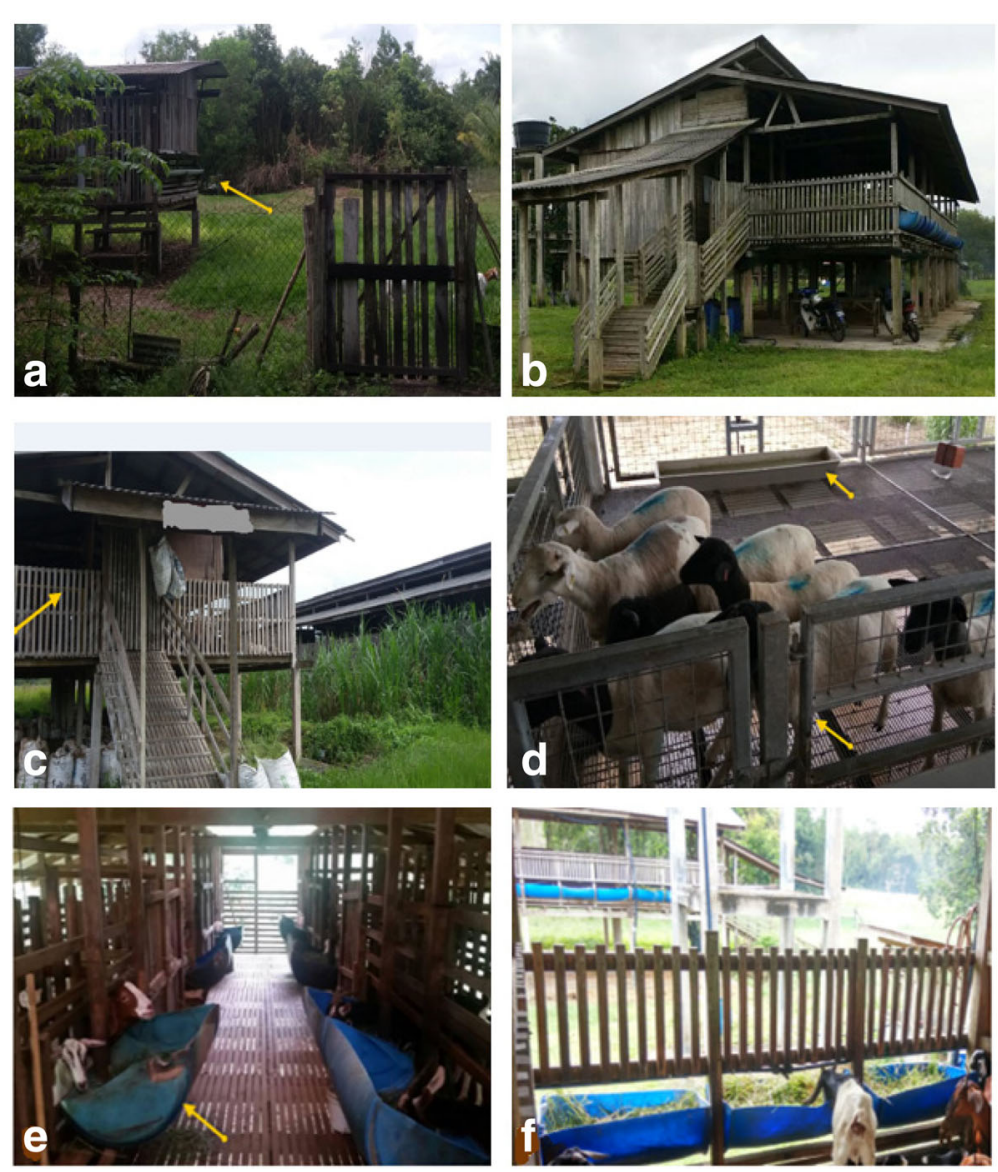

Fig. 1 Housing condition, roofing, flooring, ventilation, sanitation, Feeds and feeding management. The flooring type is wooden and elevated (a, b, c). Some may use metal fence with wooden frame and wooden flooring (d), Feeding utensils (e); and (f) pellets and grasses that for the sheep and goats

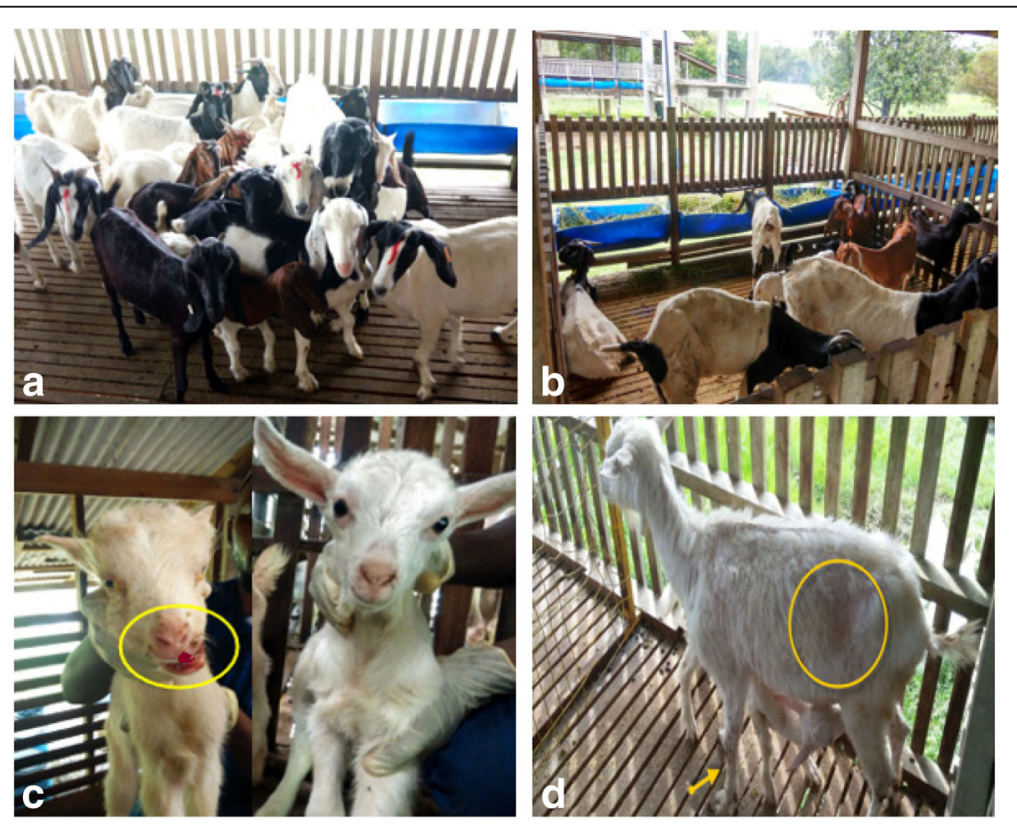

Fig. 2 Animal condition inside the pens of the intensively managed farms: healthy animals (a, b); and sick animals in isolation (c, d) with clinical disease and orf skin lesions (as indicated in the photography) 
Table 5 Respective compliance level of farms' herd health program

\begin{tabular}{lll}
\hline Farms & Compliance (\%) & Non- Compliance (\%) \\
\hline LS & 3 & 11 \\
PT & 14 & 3 \\
AB & 15 & 2 \\
LM & 14 & 3 \\
BF & 7 & 9 \\
LI & 11 & 5 \\
MF & 8 & 8 \\
LH & 8 & 8 \\
LZ & 3 & 11 \\
LB & 6 & 9 \\
LW & 6 & 9 \\
LY & 3 & 12 \\
LN & 3 & 11 \\
\hline
\end{tabular}

LH, LB and LW did not record a significant compliance level $(p>0.05)$; indicating decrease compliance level by these farms to parameters of HHP modules. The overall effect likelihood ratio of HHP program on various farms compliance levels is strong and significant $\left(X^{2}=302.61\right.$; $P<0.0001)$.

Table 7 presents the main components of HHP modules and the levels of compliances and non-compliances. Animal identification ( $\mathrm{T}$ ) recorded highest compliance level of $84.62 \%$, followed by housing condition (eg: roof, flooring, ventilation, sanitation) $(\mathrm{H})$ with value of $55.77 \%$ compliance level; moreover, milking management $(\mathrm{M})$ recorded the highest level of non-compliance of $82.69 \%$. The association amongst the main components of HHP
Table 7 Main components of HHP modules and the level of farmer's compliance and non- compliance

\begin{tabular}{lllll}
\hline HHP & $\begin{array}{l}\text { Total Number } \\
\text { module }\end{array}$ & $\begin{array}{l}\text { Level of } \\
\text { Onswers }\end{array}$ & $\begin{array}{l}\text { Level of } \\
\text { Compliance }\end{array}$ & $\begin{array}{l}\text { Non-Compliance } \\
\text { and P-Value }\end{array}$ \\
\hline H & 104 & $58(55.77 \%)$ & $46(44.23 \%)$ & $\mathbf{X}^{\mathbf{2}=\mathbf{1 1 4 . 7 7}}$ \\
F & 91 & $49(53.85 \%)$ & $42(46.15 \%)$ & $\mathbf{P}<\mathbf{0 . 0 0 0 1}$ \\
P & 91 & $39(42.86 \%)$ & $52(57.14 \%)$ & \\
D & 39 & $19(48.72 \%)$ & $20(51.28 \%)$ & \\
V & 39 & $7(17.95 \%)$ & $32(82.05 \%)$ & \\
B & 91 & $41(45.05 \%)$ & $50(54.95 \%)$ & \\
W & 65 & $35(53.85 \%)$ & $30(46.15 \%)$ & \\
C & 26 & $13(50 \%)$ & $13(50 \%)$ & \\
M & 52 & $9(17.31 \%)$ & $43(82.69 \%)$ & \\
R & 195 & $52(26.67 \%)$ & $143(73.33 \%)$ & \\
K & 182 & $85(46.70 \%)$ & $97(53.30 \%)$ & \\
E & 65 & $30(46.15 \%)$ & $35(53.85 \%)$ & \\
T & 52 & $44(84.62 \%)$ & $8(15.38 \%)$ & \\
G & 52 & $19(36.54 \%)$ & $33(63.46 \%)$ & \\
X & 65 & $16(24.62 \%)$ & $49(75.38 \%)$ & \\
Total & $\mathbf{1 2 0 9}$ & $\mathbf{5 1 6 ( 4 2 . 6 8 )}$ & $\mathbf{6 9 3}(\mathbf{5 7 . 3 5 )}$ & \\
\hline Al the & & &
\end{tabular}

All the abbreviation were defined in Table 8 above

modules and the level of compliances and non-compliance is strong and significant $\left(\mathrm{X}^{2}=114.77 ; \mathrm{P}<0.0001\right)$. Mosaic plot presentation of the main Components of HHP Modules and compliance level is shown in Fig. 3.

Figure 4 depicts the distribution of mean antibody titre among all the farms sampled. Farms LI and PT have the highest antibody titres, whereas farm LW have the lowest antibody titres. Majority of the antibody titres were below OD reading of $<0.5$.

Table 6 Compliance level to herd health program

\begin{tabular}{|c|c|c|c|c|c|c|}
\hline \multirow[t]{2}{*}{ Farms } & \multirow{2}{*}{$\begin{array}{l}\text { Test } \\
\text { Estimates }\end{array}$} & \multirow{2}{*}{$\begin{array}{l}\text { Standard } \\
\text { error }\end{array}$} & \multirow{2}{*}{$\begin{array}{l}\text { Chi square } \\
\text { value }\end{array}$} & \multirow[t]{2}{*}{$P$-value } & \multicolumn{2}{|c|}{$95 \%$ Confidence Interval } \\
\hline & & & & & Lower & Upper \\
\hline LS & -0.3433 & 0.0686 & 25.02 & $<0.0001$ & -0.4786 & -0.2093 \\
\hline PT & 1.5754 & 0.2382 & 43.73 & $<0.0001$ & 1.1248 & 2.0632 \\
\hline$A B$ & 1.9145 & 0.2619 & 53.44 & $<0.0001$ & 1.4256 & 2.4588 \\
\hline LM & 1.7029 & 0.2463 & 47.79 & $<0.0001$ & 1.2392 & 2.2100 \\
\hline $\mathrm{BF}$ & -0.2079 & 0.2096 & 0.98 & 0.3212 & -0.6266 & 0.1976 \\
\hline $\mathrm{LI}$ & 0.7577 & 0.2066 & 13.45 & 0.0002 & 0.3565 & 1.1688 \\
\hline MF & 0.1056 & 0.2040 & 0.27 & 0.6048 & -0.2981 & 0.5039 \\
\hline $\mathrm{LH}$ & 0.0619 & 0.2045 & 0.09 & 0.7623 & -0.3433 & 0.4601 \\
\hline $\mathrm{LZ}$ & -1.2280 & 0.2619 & 21.99 & $<0.0001$ & -1.7722 & -0.7390 \\
\hline LB & -0.3987 & 0.2153 & 3.43 & 0.0640 & -0.8314 & 0.0154 \\
\hline LW & -0.3499 & 0.2137 & 2.68 & 0.1015 & -0.7787 & 0.0617 \\
\hline LY & -1.4738 & 0.2835 & 27.03 & $<0.0001$ & -2.0704 & -0.9501 \\
\hline $\mathrm{LN}$ & -1.3054 & 0.2683 & 23.68 & $<0.0001$ & -1.8650 & -0.8061 \\
\hline
\end{tabular}




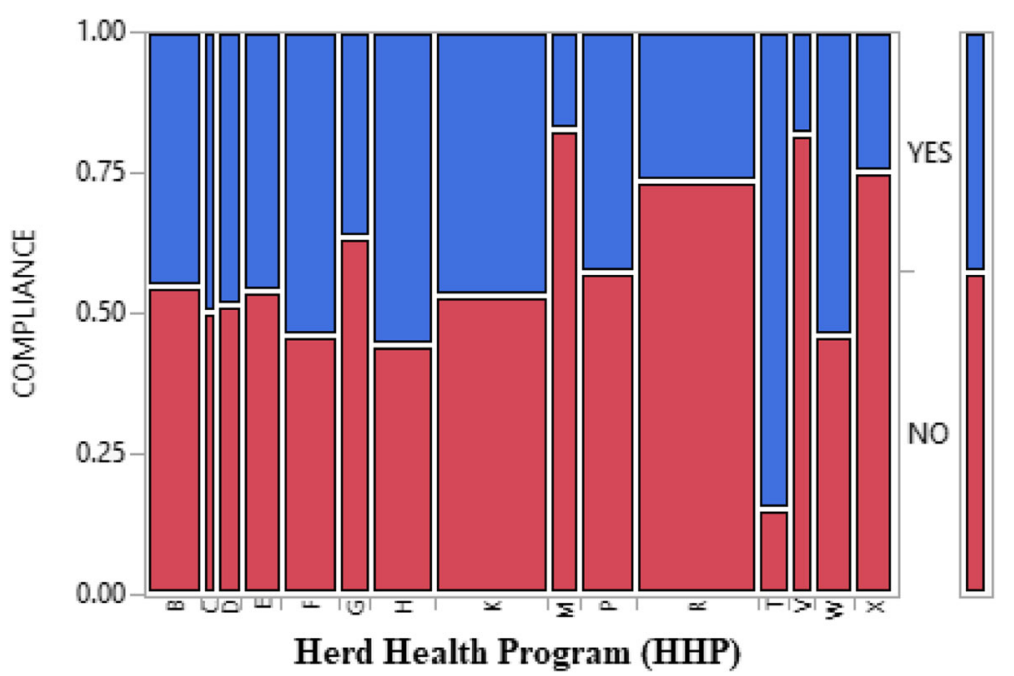

Fig. 3 Mosaic plot presentation of the main components of HHP modules and compliance level

\section{Discussion}

This investigation reported the current status of orf virus disease in the Terengganu state, eastern coast region of Peninsular Malaysia. The study revealed evidence of the presence of orf virus infection among the sheep and goats' population as confirmed by ELISA assay which amounted to a prevalence of $16.8 \%$ in sheep and $25.1 \%$ in goats. Replication of Orf virus occurs in the epithelial cell surfaces of the skin layers and at the mucosa of the mouth, oesophagus as well as hairless parts of the body serving as primary sites of the lesions. Accidental abrasions of the skin due to hard stubble, thistles or any analogous plant promote access of the virus and initiates the replication cycle [28-31]. Upon successful entry and attaining the incubation period of approximately 10 days the disease is disseminated to the other tissue and host's response is mounted and therefore this will lead to the production of antibodies that could be detected in body fluids such as blood, saliva and mucosal secretions [22, 32]. Several studies have stated that clinical orf virus symptoms are first seen in the fourth and fifth days of exposure, whereas the levels of anti-orf virus specific antibodies are normally detectable between eighth and tenth days of exposures to the virus.

ELISA test employed in this study revealed an overall seroprevalence rate of $22.8 \%$ based on antibody titre

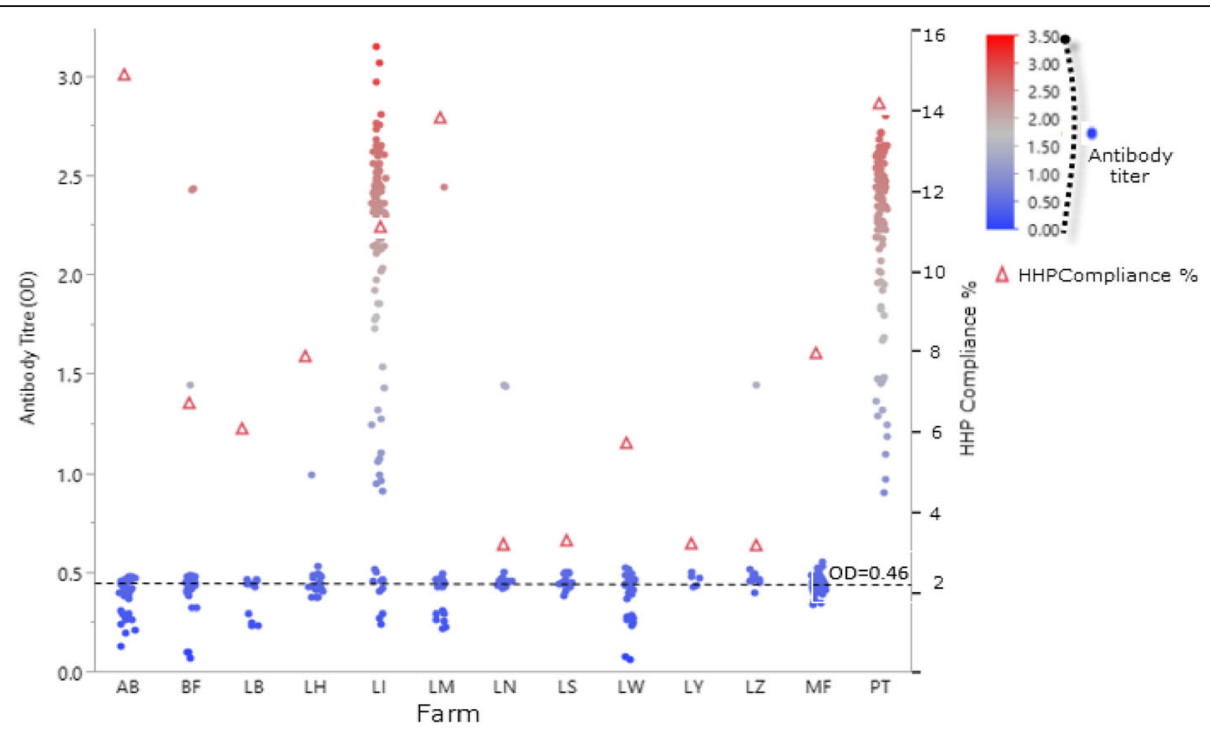

Fig. 4 Unequal distribution of antibody titres (based on OD reading) against orf virus among animals in the respective farms. Each data point in the graph represents antibody titre of individual animal. The horizontal line (---) represents cut-off point of OD for negative sera (negative results). HHP compliance level (in \%) for the respective farms 
among the sampled population. This indicates a considerably high sero-conversion rate of the disease compared with a similar study in the Selangor, Malaysia with a prevalence rate of $14.4 \%$ in goats and $12.2 \%$ in sheep [27]. However another report by Jesse et al. [26] which was high prevalence rate (36.7\%) among goat population, based on IgM detection observed and thus indicates an active infection in that State. Generally, it is suggested that orf disease is a serious issue in Malaysia which is recurring frequently at an alarming rate in different parts of the country [26]. Similarly, consistent with our findings, the prevalence of orf in other parts of the world is high [22]. Orf infection reported was 19.51\% among lamb in England [24], 34.89\% in China [11], staggering 98\% Nilgiri Hills in Tamil Nadu, India [33] and 54\% in Saudi Arabia [34]. Gökce et al. [28] had also reported a high sero-conversion rate of $52.8 \%$ among lambs within some selected districts in Turkey. The high morbidity of this disease underscores the infectious nature of this virus and its economic impact on the goat industry $[9,22,35]$. It has been speculated that contagious ecthyma disease of sheep does not confer long term protection thus, seasonal outbreaks among herds are common [36, 37]. Shed viruses from animals remains viable for decades as such they served as source for the sporadic spread of the virus in the same herd. Thus resulting in the ultimate transmission of the virus to neighbouring herds via transporting of infected animals.

Various putative risk factors for the prevalence rate were examined to ascertain the possible risk factors. Identification of relevant risk factors is crucial for the proper disease management and outbreak containments. We identified species, age and sex of the animal to be the most significant risk factors. Goat species recorded highest prevalence of $25.1 \%$ compared to $16.8 \%$ that of ovine like the report by Jesse et al. [26]. Naturally, goats are naturally more aggressive than ovine, hence they tend to cause injury among themselves leading to higher susceptibility to orf virus transmitted via direct contact. Additionally, most small holders do not practice dehorning for their animals, as such this may subject the animals to injuries due to fighting. Animals could easily get wounded, cuts and abrasions as a predisposal factor for virus penetration via a wounded skin [38-41].

Similarly, female gender had the highest prevalence and this was recorded as a significant risk factor in this study. A similar observation was reported by Orgeur et al. [38]. More aggressive behaviour of males expected to contribute higher number of cases. However, unequal sample size by which majority of the subjects studied were female may contribute to our unparallelled observation. Meanwhile, previous observations showed that orf infection have not discriminatory tendencies between gender $[22,42]$.

Among the 13 farms, farm LY showed the highest historical orf virus infection. This is strongly associated with the fact that farm LY recorded the highest noncompliance levelof HHP. A strict adherence to HHP modules shall reduce the general risk of exposure to contagious ecthyma disease in animal population [43, 44]. Animals are susceptible to orf virus infection regardless of their age. There is a moderate morbidity rate of approximately $50 \%$ in the affected farms observed in this study, however, the mortality rate of approximately $1 \%$ was identied in the affected farms. Interestingly, higher seroprevalence $(100 \%)$ was observed among kids younger than 3 months of age in comparison to animals older than 4 months, however, this high seroprevalence among the kids has not been associated with high mortality, therefore a more detail confirmatory test such as virus culture and isolation would further distinguishes active infection that neccesiates for vaccination. Furthermore, we do not observed a very a high significant difference between the flocks show clinical disease and the high seroconversion. A similar phenomenon was observed by Bora et al. [36] who studied the prevalence of contagious ecthyma among goats in Assam, India. This observation is attributed to the fact that older animals developed better protective immunity against recurrence orf infection.

Other risk factors examined such as the presence lesion and abrasion, history of clinical orf infection in farms and vaccination practice did not appear to be a significant determinant of orf disease prevalence. The presence of skin lesions usually indicates current infections which are best diagnosed by standard virus isolation and identification $[7$, 45]. Antibodies produced by animal hosts as a part of either primary or secondary immune response and detected during the latter part of an infection. It may take 1 to 4 weeks following an infection before antibodies can be detected and assayed in ELISA test. Animals with previous exposure to orf virus may carry the virus in their hide or dried scabs and shed the virus into the surrounding environment. Orf virus had a higher survivability in the environment especially in tropical climate [46]. In an endemic environment, similar to other viral diseases, animals are often re-infected with orf especially when they become immunosuppressed [22, 47]. Additionally, previous orf infection does not provide a long-lasting immunity against orf but instead it provides farmers an experience to deal with subsequent infections. Animals that were reinfected often recovers faster compared to the first exposure and shows less severe lesions [46]. Vaccination had been a main prophylactic measure against Orf. Another issue is immunity induced from vaccination which can only last for about 6 months. Booster doses of vaccine were required especially for farms located in areas endemic with orf [48-51].

The HHP module analysed in this study contains variables that are pertinent to epidemiology of orf disease as previously described elsewhere [24, 52, 53]. Unfortunately, all the farms surveyed did not incorporate orf 
immunization as a part of their HHP. Vaccination of already infected animals has been found to reduce the course and severity of the disease [54]. Our results also indicated that orf virus infection is widespread in the areas of Terengganu State as such vaccination should have been advocated on a regular basis. Even though, some authors are in the opinion that a vaccine against orf disease should not be attempted in herds that do not have previous history of the disease since only live vaccines are available [55]. However, newer effective potential vaccine tried in some experimental animal revealed promising results, it is therefore advisable to vaccinate animals against orf regardless of previous outbreak in the farms [27, 50].

The general objective of HHP is to enhance the herd efficiency through general farming, nourishment administration, vaccination, ecological management and parasite control. It endeavors to arrange all data appropriate to goat crowd wellbeing into a straightforward, usable, and effectively recalled lists. Therefore, a proper recordkeeping must be in place to enable and ensure the success of HHP [43, 44]. Vaccination is important to shorten the duration of disease transmission and to confine infections from being spread from animal to animal. As indicated by Steven and Jeremy [56], vaccination programs are intended to contain future infections in the flock and ought to be implemented together with neighboring farms. In Malaysia, the present vaccination experience is targeted against FMD and pneumonia which was not in practice by all farmers in the survey. Our study had successfully and thoroughly surveyed the existing HHP at the farms. An overall compliance level of $42.7 \%$ observed is lower than that previously reported by Abdullah et al. [43] on several farms with a compliance level of 56\%. Good HHP supervision is a rehearsal target to prevent the expansion and spread of diseases thus reduces economic losses among farmers [57].

Disease monitoring is concerned with understanding changes in its endemicity and distribution [58]. Proper biosecurity measures such as foot dip, vehicle spray, use of proper boots and attire in the farms were not implemented. Interview with small holder farmers also revealed a lack of awareness of what are the main goals of herd health programme. Farms surveyed usually practised intensive management system due to limited availability of land to rear their goats. This caused the likelihood of animals contracting orf virus infection due to an increase of crowding among animals [27, 32].

Among the 14 main components of HHP modules, milking management is observed to have the highest level of non-compliances $(82.69 \%)$, whereas, animal identification had recorded highest compliance level of $84.62 \%$. The highest compliance level associated with animal identification indicated an appreciable livestock production is in accordance with the standard recommended by the OIE.
Herd-health information is pertinent to livestock producers and to the public as well as animal welfare, fully comprehending of types and sources of animal's heath that farmers will utilized is very vital [59].

Many studies carried on the relationship between dose antibody responses and virus replication have generated controversies [60-63] The level of humoral immune response against the virus is directly related to the level of virus replication achieved [64, 65]. Titers of antibodies are normally positively correlated with the level of total virus binding antibody titers [66-68]. Therefore, it shall be a significant association amongst total virus production in the host and the humoral responses of antibody titres as directed against important viral disease such influenza [63]. However, in many cases, high antibody titre does not necessarily translate into protection against reinfection and previously exposed animals to orf viruses do not necessarily enjoy protection against re-infection [69]. We noted that despite the high compliance level to HHP, many animals in farms LI and PT had high antibody titres against orf virus. Due to the fact that no vaccination against orf virus was given and no current clinical infection was observed, it is suggested that the cohort group were suspected to have recovered from recent infection following an increase in antibody titres against the virus. The vaccination shall contribute the most significant weightage towards the success of HHP entirely. In addition, watchful understanding of the different types of protective immunity against orf virus is important for the development of a safer vaccines and containment of virus spread.

Control and prevention of Orf disease is important to ensure it does not widely spread in the entire animal population [70-73]. A viable animal health program is a fundamental piece of an effective animal production, herd heath program (HHP) is an essential tool for monitoring disease for prevention and control programs [43, 56]. Legitimate sustaining and rearing won't bring about most extreme generation if goats are not healthy, there's a scarcity of knowledge concerning the farmers' compliance level on correct herd health program practiced by the livestock farmers in Malaysia. This information is very important to increase the productivity of the farms and for future development of temporary herd health programs for small ruminant farms.

\section{Conclusions}

Interaction between virus and body immune system is a battle among the parties (virus and host). In primary orf virus disease, the virus replicates in the epithelial cells for a period before the host can mount an effective immune response. This leads to an appearance of IgG or IgM that were incriminated as a signal of orf infection. The overall prevalence was found to be $22.8 \%$ (25.1\% in 
goats and $16.8 \%$ in sheep). Significant risk factors identified were specie, age, and sex. A higher sero-conversion rate was seen among kids younger than 3-months-old and female gender showed higher antibody titre. Poor implementation of HHP may also be associated with a higher sero-conversion rate of orf virus infection observed. Therefore, it is important to carry out epidemiological surveys $[74,75]$ in circumstances where there is a risk of introducing disease into a new herd through replacement of sheep from unknown premises. Based on our findings, it will be recommended that lambs in the region should be regularly vaccinated to reduce the severity of Orf and its consequential financial implications, along with routine vaccination, periodic surveillance could be enacted to determine the both temporal and spatial distribution of Orf viruses.

\section{Methods}

\section{Informed consent and ethical consideration}

All the procedures involving animal subjects were conducted in compliance with the recommendations of the Institutional Animal Care and Use Committee (IACUC) UPM/IACUC/AUP-U013/2018. Goats and sheep from thirteen (13) farms were selected among the private and government owned farms at 4 districts of the Terengganu state. The sampling farms were selected on the basis for the availability of adequate study animals and diversity in agroecology of the areas. Terengganu State is divided into eight (8) administrative districts called Daerah in Malay language. The sampling was strategized to capture 4 out of the 8 eight administrative districts as the representative of this state and a total of 13 farms were selected based on the simple random sampling technique. Consent from all participating farms were obtained through written permission of the owners and witnessed by the Terengganu State division of the Department of Veterinary Service (DVS).

\section{Questionnaire and data collection}

A well-structured questionnaire which contained information on farm management practices, possible risk factors and herd health programme implemented by farm owners were filled via an interview session. The questionnaire was designed to contain three (3) sections, namely; Section A (farm management practice), Section B (farm's HHP compliance level) and Section $C$ (demography and risk factors for exposure of individual animals). The questionnaire template was added separately in the Additional file 1.

\section{Farm data collection}

Section A of the questionnaire which relates to informations on the sampled farms was administered. The relevant data sought included; details of the operator, category of farmer, man-power, annual production, type of housing and management system, as well as population. Section B on the other hand (farmer's compliance level to HHP), contains questions relating to the farmer's awareness, compliance level, and knowledge of each of the 14 modules of herd health programs, based on the Department of Veterinary Service, Malaysia (Table 8). Lastly, section C of the questionnaire contains the information on the demography namely; age, sex, and breed, together with information on the putative risk factors such as cut and abrasion on the animal, presence of orf lesion and history of vaccination against orf or any related viral disease.

\section{Sampling of farms}

This investigation involved thirteen (13) sheep and goat farms located at the four major districts namely; Kuala Terengganu, Kuala Nerus, Marang and Setiu in the Terengganu State, East Malaysia. The respondents were given the questionnaire; a response to each question is a dichotomous outcome as either "YES" or "NO". Where "YES" denotes the farmers' compliance to that segment of HHP module, while "NO" is otherwise.

\section{Individual animal data collection}

A Thorough physical examination to identify infected animals based on the clinical signs of erythema, papule, vesicle, or pustule around the lip, gums, mouth and tongue and the general body part was conducted. Relevant demographic data from each animal was also recorded in the data sheet prior to sampling. A total of 504 sheep and goat's samples were collected using simple random sampling method after calculating the sample size according to the standard formula $[76,77]$. The formulae and the sample size calculation were as in shown below. After sample collection all the involved animals were closely monitored regularly to avoid any spread of the disease.

$$
\mathrm{n}=\frac{Z^{2} p q}{L^{2}}
$$

where, $\mathrm{n}=$ sample size

$\mathrm{Z}=$ Standard normal distribution at $95 \%$ confidence interval $=1.96$

$\mathrm{p}=$ Prevalence in similar work

$\mathrm{q}=1-\mathrm{p}$

$\mathrm{L}=$ Allowable error, taken as $5 \%=0.05$

In this study, $P=36.7 \%$ (Jesse et al., 2018a)

$\mathrm{n}=\frac{Z^{2} p q}{L^{2}}=\frac{(1.96)^{2} \times 0.367 \times(1-0.0732)}{(0.05)^{2}} \approx 500$ samples

\section{Preparation of serum sample}

Whole blood samples were collected from all the 504 animals in the sampling farms as. A method of collection via jugular venepuncture using a 21 gauge vacutainer needle was applied and collected into a plain serum 
Table 8 Herd health program modules

\begin{tabular}{|c|c|c|c|c|}
\hline $\mathrm{S} / \mathrm{N}$ & Main component of HHP Module & $\begin{array}{l}\text { Notation } \\
\text { Acronym }\end{array}$ & Sub-questions & $\begin{array}{l}\text { Total number } \\
\text { of Questions }\end{array}$ \\
\hline 1 & Housing condition (eg: roof, flooring, ventilation, sanitation) & $\mathrm{H}$ & $\mathrm{H} 1$ to $\mathrm{H} 8$ & 8 \\
\hline 2 & Feed and feeding management (feed storage, amount of feed required per animal) & $\mathrm{F}$ & F1 to F7 & 7 \\
\hline \multirow[t]{3}{*}{3} & \multicolumn{4}{|l|}{ Parasite control program } \\
\hline & a. deworming program & $\mathrm{P}$ & P1 to P7 & 7 \\
\hline & b. deticking & D & D1 to D3 & 3 \\
\hline 4 & Vaccination program & V & $\mathrm{V} 1$ to $\mathrm{V} 3$ & 3 \\
\hline 5 & Farm biosecurity & B & B1 to B7 & 7 \\
\hline 6 & Waste disposal & W & W1 to W5 & 5 \\
\hline 7 & Fly, pest and odour control & C & $\mathrm{C} 1$ to $\mathrm{C} 2$ & 2 \\
\hline 8 & Milking management (mastitis control program) & M & $\mathrm{M} 1$ to $\mathrm{M} 4$ & 4 \\
\hline 9 & Reproductive management & $\mathrm{R}$ & R1 to R15 & 15 \\
\hline 10 & Kid/lamb management & K & $\mathrm{K} 1$ to $\mathrm{K} 14$ & 14 \\
\hline 11 & Doe/ewe management & $\mathrm{E}$ & E1 to E5 & 5 \\
\hline 12 & Animal identification & $\mathrm{T}$ & T1 to T4 & 4 \\
\hline 13 & Medication/Drug management (record system, storage) & G & G1 to G4 & 4 \\
\hline 14 & Disease monitoring program & $x$ & $\mathrm{X} 1$ to $\mathrm{X} 5$ & 5 \\
\hline \multicolumn{2}{|c|}{ Total main HHP modules 14} & \multicolumn{3}{|c|}{ Total number of questions 93} \\
\hline
\end{tabular}

collection tubes. The tubes containing the whole blood samples were then stored in a cooler box and transported to the laboratory for analysis. The blood samples were left to clot and centrifuged at 3,000 revolution per minute (rpm) for $5 \mathrm{~min}$ to separate the serum from the blood. The serum was then pipetted into a $1.5 \mathrm{ml}$ microcentrifuge tubes and stored at $-20^{\circ} \mathrm{C}$ until required for assay.

\section{Preparation of hyperimmune positive and negative sera against the pure Orf virus}

Hyperimmune serum (HIS) against the UPM1/14 Orf virus isolate was prepared according to the method described by [34, 36, 78-80]. For this purpose, specific antiOrf virus antibodies were prepared in two healthy goats of about 1 year old. Blood sample were collected as the negative control prior to the start of the procedure. The purified virus suspension contained in DMEM medium was first heat inactivated by incubation at $56^{\circ} \mathrm{C}$ for $30 \mathrm{~min}$. One $\mathrm{mL}$ of the pure Orf virus antigen was mixed with Complete Freud's Adjuvant (CFA) (GIBCO BRL, USA). An emulsion containing equal volume of pure virus and CFA was formed by homogenization until a good mixture was obtained. The emulsified suspension was allowed to settle at $4{ }^{\circ} \mathrm{C}$. One goat was then injected subcutaneously with $0.5 \mathrm{~mL}$ of this emulsion while the other goat was kept as control. Two weeks later, the goat was re-injected with the same dose of antigens that was emulsified in Incomplete Freund's Adjuvant (IFA) (GIBCO BRL, USA). The injections were then repeated weekly for 4 weeks. One week after the last injection, the goat was injected finally with live virus (without adjuvant) at the last week. Two weeks after the last injection bleeding was carried out from the goat. The blood was allowed to clot at room temperature and spun at $1000 \mathrm{rpm}$ for $5 \mathrm{~min}$, hyperimmune serum was harvested, the antibody titer was determined by ELISA. The HIS showing the highest antibody titer was aliquoted and distributed in $1 \mathrm{~mL}$ quantity stored at $-20{ }^{\circ} \mathrm{C}$ until further required. Therefore, this HIS was employed in the ELISA test as a positive reference sera while pre-immune sera collected from experimental animal used as negative control.

\section{Serological screening and assay procedures Orf virus antigen and determination of Orf virus total protein concentration}

The serological screening was done using an in-house developed antigen-coated ELISA. The virus antigen used for the coating of ELISA plate was a local orf virus isolate (UPM1/14) obtained from the Virology Laboratory, Faculty of Veterinary Medicine of the University Putra Malaysia from previous outbreak cases of contagious ecthyma [10]. This virus was propagated in lamb testicle cell (LT) monolayers as described by Bala et al. [27] and Abdullah et al. [10]. Upon propagation, the virus was concentrated in polyethylene Glycol (PEG) and purified in a cushion of $36 \%$ sucrose gradient and $10-50 \%$ sodium diatrizoate gradient [81]. The virus pellet obtained was reconstituted in sterile phosphate buffered saline 
$\mathrm{pH} 7.4$ and kept at $-70{ }^{\circ} \mathrm{C}$ until required. The total protein concentration of purified Orf virus was determined using Bradford assay method, total Orf virus concentration in the virus solutions was determine with aid of prism 5 software by plotting the protein concentration against the corresponding absorbance to obtain a standard curve.

\section{Optimization of ELISA reagents}

The working concentrations for Orf antigen, conjugate and antibodies were optimized using standard protocol of chequerboard titration adopted from Babiuk et al., [82]; Bhanuprakash et al., [83]; Niang, [84]; Azmi and Field, [85] with some minor changes. The positive and negative control sera obtained from post-vaccinated and prevaccinated animals were tested using a two-fold dilution. The optimal dilution the Orf virus antigen and reference HIS positive sera were selected using the antigen and serum dilutions that gave maximal difference in reading of the absorbance between positive and negative sera.

\section{ELISA procedure}

An enzyme linked immunosorbent assay (ELISA) was developed in-house as described by Azmi and Field [85] with minor modifications. All reagents including conjugate, substrate, buffers and washing procedures of plates were prepared according to standard procedures. ELISA test procedure was conducted by an initial coating of the 96-well plate specially designed for use in ELISA assays (Dynatech Immunolon, USA) [86]. The working volume of each of the reagents was $50 \mu \mathrm{l}$. Purified orf virus antigen was diluted in sodium hydrogen carbonate $\left(\mathrm{NaHCO}_{3}\right)$ buffer ( $\mathrm{pH}$ 9.6) to give a final concentration of $10 \mu \mathrm{g} / \mathrm{ml}$ antigen protein, and $50 \mu \mathrm{l}$ of this was used for coating of the plate and then incubated at $4{ }^{\circ} \mathrm{C}$ overnight. Following overnight incubation, the plate was washed three times with Phosphate Buffered Saline Tween-20 (PBST), the washing was carried out manually by filling each of the well with $200 \mu \mathrm{l}$ of the washing buffer, with the aid of a multi-channel micropipette, and then allowed to stand for a few seconds before discarding. This wash procedure was repeated 3 times. After washing $50 \mu$ of $2 \%$ of Fraction V (Bovine Serum Albumin (BSA)) (Sigma, UK) was added and the plate was incubated at $45^{\circ} \mathrm{C}$ for $2 \mathrm{~h}$, in order to block any unspecific unbound antigens. Upon completion of the incubation, the plate was again washed three times with PBST-tween-20. A two-fold dilutions of the test sera were added to the plate and incubated at $37^{\circ} \mathrm{C}$ for $1 \mathrm{~h}$ before the plate was washed 3 times using the same wash buffer. A pre-diluted rabbit anti-goat (for goat serum) and anti-sheep (for sheep serum) peroxidase conjugated immunoglobulin G (KPL, USA) was added and allowed to react with the antigen bound goat/sheep antibodies by incubation at $37^{\circ} \mathrm{C}$ for $1 \mathrm{~h}$. The plate was then washed 3 times and the substrate $2-2^{1}-$ Azino-bis (3-ethylbenzthioline -6-sulfonic acid) ABTS diluted in citrate phosphate buffer (containing $0.0130 \%$ hydrogen peroxide $\left.\left(\mathrm{H}_{2} \mathrm{O}_{2}\right)\right)$ was added and the plate was incubated at room temperature for $30 \mathrm{~min}$. At the end of the incubation period, the optical density was read at $450 \mathrm{~nm}$ in an ELISA reader (TECAN Infinite M200).

\section{Determination of cut off value}

The value for ELISA cut-off threshold for tested samples at an optimized dilution of all the reagents was determined by taking the mean absorbance (O.D) reading of pre-immune negative sera plus three standard deviations $[36,82]$ $($ mean + S.D.; mean $=0.17$; S.D. $=0.097$, three times S.D. $=$ 0.291 therefore $\mathrm{CV}$ is equal to 0.461 ). Any sample(s) with $\mathrm{O}$. $\mathrm{D}$ reading above this $\mathrm{CV}$ was considered as positive for anti-Orf virus antibodies. Therefore, all the O.D. readings obtained from sera of animals were interpreted as positive when the value is greater than the cut-off value or deduced as negative if the value is otherwise.

\section{Testing for cross-reactivity of ELISA assay}

As a means of quality control of this in-house ELISA and in order to rule out any cross reactivity of this ELISA assay with similar virus of small ruminants, a panel of positive sera for Blue tongue (BTV) and Schemallenburg (SBV) viruses were tested using this developed ELISA. This positive BTV and SBV sera samples were available in the virology laboratory of the Universiti Putra Malaysia which were initially collected from confirmed disease cases occurring among some farms.

\section{Sensitivity and specificity of the ELISA assay}

The sensitivity and specificity of the ELISA employed in this study was determined based on the true positive and false negative value subjected to analysis and interepreted from the optimal cut-off point described elsewhere [36, 82, 83]. Both sensitivity and specificity values were calculated using Receiver Operating Characteristics (ROC) curves with the aid of MedCalc software (MedCalc Statistical Software version 18.11 (MedCalc Software bvba, Ostend, Belgium; http://www.medcalc.org; 2018).

\section{Data analysis}

Information procured for both Sections A and B of the questionnaires was incorporated into Microsoft Office Excel and analysed using JMP software. The likelihood ratio and regression model were used to evaluate the farmer's compliance level towards HHP. Responses to each sub-unit questions of the 14 major components modules of HHP (Table 8) were expressed as percentage to indicate overall farmers' compliance level and their association determined after subjecting the result to chi- 
squre analysis with the aid of JMP Statistics software (SAS Campus Drive, USA). Similarly, all the data obtained from section $B$ (demography and risk factors for exposure of individual animals) as well as the ELISA results were incorporated into the JMP software version 14, and analysed for prevalence rate and association of each risk factor using chi-square test.

\section{Additional file}

Additional file 1: Questionnaire. (DOCX 59 kb)

\section{Abbreviations}

ABTS: 2-2' - Azino-bis (3-ethylbenzthioline - 6-sulfonic acid); BSA: Bovine Serum Albumin; DVS: Department of Veterinary Services; ELISA: Enzyme Linked Immunosorbent Assay; $\mathrm{H}_{2} \mathrm{O}_{2}$ : Hydrogen peroxide; HHP: Herd Health Program; IACUC: Institutional Animal Care and Use Committee; MARDI: Malaysian Agricultural Analysis and Development Institute; MESTECC: Ministry of Energy, Science, Technology, Environment \& Climate Change; MOSTI: Ministry of Science, Technology and Innovation Sciencefund; $\mathrm{NaHCO}_{3}$ : Sodium Hydrogen Carbonate; O.D: Optical Density; PBST: Phosphate Buffered Saline Tween 20; PEG: Polyethylene Glycol; rpm: Revolution Per Minute; UVH: University Veterinary Hospital; $X^{2}$ : Chi Square

\section{Acknowledgments}

The authors wish to acknowledge the entire management of Department of Veterinary Service, Terengganu, Malaysia, for their assistance and their professional services rendered during the sampling and our profound appreciation goes to University Veterinary Hospital (UVH), and Faculty of Veterinary Medicine Universiti Putra Malaysia for providing the necessary supports.

\section{Authors' contributions}

The authors were hereby given a declaration that this work was done by all of them named in this paper and all liabilities pertaining to claims relating to the content of this article will be borne by them. JAB, MLMA, KNB, MTG, MSBSN, and LKM conceived the idea, participates in data collection and run the test. MLMA, MMN, AWH, RBM and all participated in conceptualization of the idea, study design, review, and editing of paper, JAB, LA, AAA and HKM participated in the all statistical analyses and interpretation as well as preparation of the manuscript draft. All authors have read and agreed with submission of final paper to the journal.

\section{Authors' information}

MLMA author is a PhD holder (1994), currently a serving Professor at Universiti Putra Malaysia (Former deputy vice chancellor research and innovation of the Universiti Putra Malysia) with expertise in virology, immunology and vaccine technology.

MMN author is a PhD holder (1992), currently a serving Professor at Universiti Putra Malaysia with expertise in Environmental \& Nutrition Pathology. AWH author is a PhD holder (1993) currently a serving Professor at Universiti Putra Malaysia with expertise in Theriogenology (Animal Reproduction). LA author is a PhD holder (2014) currently a serving Associate Professor at University of Maiduguri, Nigeria with expertise in Equine Medicine. RBM author is a PhD holder currently holding position of a Director at the Veterinary Research Institute at Ipoh, Perak, Malaysia.

MTG is a PhD holder author is currently holding position of a Director at the Terengganu State Department of Veterinary Services, Malaysia. $J A B$ author is a PhD student at the Universiti Putra Malaysia and holding position of Lecturer at Bayero University Kano, Nigeria with expertise in Virology, Immunology and vaccine technology.

KNB author is a PhD student at the Universiti Putra Malaysia and holding position of a Lecturer at Monash University Malysia with expertise in Molecular biology, vaccine and therapeutics.

HKM author is a PhD student at the Universiti Putra Malaysia and holding position of Lecturer at University of Maiduguri, Nigeria with expertise in Virology.
AAA author is a PhD student at the Universiti Putra Malaysia and holding position of Lecturer at Taiz University, Taiz, Yemen with expertise in Virology and Pharmacology.

MSBSN author is a Doctor of Veterinary Medicine from the Universiti Putra Malaysia and holding position of Veterinary Officer.

LKM author is a Doctor of Veterinary Medicine from the Universiti Putra Malaysia and holding position of Veterinary Officer.

\section{Funding}

The work was supported by the grant Ministry of Energy, Science, Technology, Environment \& Climate Change (MESTECC) formerly known as Ministry of Science, Technology and Innovation Sciencefund (MOSTI), Biotechnology Cluster 02-01-04-SF2459 (Grant no: 5450820). MESTECC supported entirely this project starting from design of the study, collection, analysis, and interpretation of data.

\section{Availability of data and materials}

The datasets generated and/or analysed in the present study are not available to the public since it belongs to the Universiti Putra Malaysia, however, data can be made available upon request by contacting Prof. Dr. Mohd Azmi Mohd Lila via email azmi@upm.edu.my.

\section{Ethics approval and consent to participate}

Ethical approval for was obtained from the Institutional Animal Care and Use Committee (IACUC) of the Universiti Putra Malaysia. Informed consent form was filled by the animal owners whom are farm managers/directors that participated in the study.

\section{Consent for publication}

Not applicable.

\section{Competing interests}

The authors declare that they have no competing interests.

\section{Author details}

'Virology Unit, Department of Pathology and Microbiology, Faculty of Veterinary Medicine, Universiti Putra Malaysia, 43400 Serdang, Selangor, Malaysia. ${ }^{2}$ Microbiology Unit, Department of Medical Laboratory Science, Faculty of Allied Health Sciences, Bayero University Kano, P.M.B. 3011, Kano, Nigeria. ${ }^{3}$ Institute of Bioscience, Universiti Putra Malaysia, 43400 Serdang, Selangor, Malaysia. ${ }^{4}$ Department of Microbiology, Faculty of Applied Science, Taiz University, Taiz, Yemen. ${ }^{5}$ Department of Veterinary Clinical Studies, Faculty of Veterinary Medicine, Universiti Putra Malaysia, 43400 Serdang, Selangor, Malaysia. ${ }^{6}$ Department of Microbiology, Faculty of Science, University of Maiduguri, P.M.B 1069, Maiduguri, Borno, Nigeria. ${ }^{7} J a b a t a n$ Perkhidmatan Veterinar Negeri Terengganu Peti Surat 203, 20720 Kuala Terengganu, Malaysia. ${ }^{8}$ Institut Penyelidikan Haiwan, (IPH), Veterinary Research Institute, Ipoh, 59, Jalan Sultan Azlan Shah, 31400 Ipoh, Perak, Malaysia.

Received: 3 August 2018 Accepted: 8 July 2019

Published online: 18 July 2019

\section{References}

1. Hani H, Ibrahim TAT, Othman AM, Lila M-AM, BtAllaudin ZN. Isolation, density purification, and in vitro culture maintenance of functional caprine islets of Langerhans as an alternative islet source for diabetes study. Xenotransplantation. 2010;17(6):469-80. https://doi.org/10.1111/j.1399-3089.2 010.00616 .

2. Hani H, Allaudin ZN, Mohd-Lila M-A, Ibrahim TAT, Othman AM. Caprine pancreatic islet xenotransplantation into diabetic immunosuppressed BALB/ c mice. Xenotransplantation. 2014;21 (2):174-82. https://doi.org/10.1111/ xen.12087.

3. Razis AFA, Ismail EN, Hambali Z, Abdullah MNH, Ali AM, Lila MAM. The periplasmic expression of recombinant human epidermal growth factor (hEGF) in Escherichia coli. Asia Pac J Mol Biol Biotechnol. 2006;14(2):41-5.

4. Ismail R, Allaudin ZN, Lila MAM. Scaling-up recombinant plasmid DNA for clinical trial: current concern, solution and status. Vaccine. 2012;30(41):591420. https://doi.org/10.1016/j.vaccine.2012.02.061.

5. Zamri-Saad M, Effendy AWM, Israf DA, Azmi ML. Cellular and humoral responses in the respiratory tract of goats following intranasal stimulation 
using formalin-killed Pasteurella haemolytica A2. Vet Microbiol. 1999;65(3): 233-40. https://doi.org/10.1016/S0378-1135(898)900298-3.

6. Venkatesan G, Balamurugan V, Bora DP, Yogisharadhya R, Prabhu M, Bhanuprakash $V$. Sequence and phylogenetic analyses of an Indian isolate of orf virus from sheep. Vet Ital. 2011;47(3):323-32 Retrieved from http:// www.ncbi.nlm.nih.gov/pubmed/21947970.

7. Bala JA, Balakrishnan KN, Abdullah AA, Mohamed RB, Haron AW, Jesse FFA, Mohd-Azmi ML. The re-emerging of orf virus infection: a call for surveillance, vaccination and effective control measures. Microb Pathog. 2018a;120:55-63. https://doi.org/10.1016/j.micpath.2018.04.057.

8. Tedla M, Berhan N, Molla W, Temesgen W, Alemu S. Molecular identification and investigations of contagious ecthyma (Orf virus) in small ruminants, north West Ethiopia. BMC Vet Res. 2018;14(1):13. https://doi.org/10.1186/s12 917-018-1339-X.

9. Sadiq MA, Abba Y, Jesse FFA, Chung ELT, Bitrus AA, Abdullah AA, Balakrishnan KN, Bala JA, Mohd Lila MA. Severe persistent case of contagious Ecthyma (Orf) in goats. J Anim Hlth Product. 2017;5(1):24-8. https://doi.org/10.14737/journal.jahp/2017/5.1.24.28.

10. Abdullah AA, Ismail MFB, Balakrishnan KN, Bala JA, Hani H, Abba Y, MohdLila MA. Isolation and phylogenetic analysis of caprine Orf virus in Malaysia. VirusDisease. 2015a;26(4):255-9. https://doi.org/10.1007/s13337-015-0278-4.

11. Gao Y, Zhao Y, Liu J, Zhou M, Liu H, Liu F, Yang W, Chen D. Orf in goats in China: prevalence and risk factors. J Agric Sci Technol A. 2016;6:116-23.

12. Haig DM, Mercer AA. Orf. Vet Res. 1998;29(3-4):311-26.

13. CFSPH (2015): http://www.cfsph.iastate.edu/Factsheets/pdfs/contagious_ ecthyma.pdf.

14. Fleming SB, Wise LM, Mercer AA. Molecular genetic analysis of orf virus: a poxvirus that has adapted to skin. Viruses. 2015;7(3):1505-39. https://doi. org/10.3390/v7031505.

15. Kinley GE, Schmitt CW, Stephens-devalle J. Case report A case of contagious Ecthyma (Orf Virus) in a nonmanipulated laboratory Dorset Sheep (Ovis aries ), 2013.Article ID 210854, 5 pages, 2013; 2013. https://doi.org/10.1155/2 $013 / 210854$

16. Li W, Ning Z, Hao W, Song D, Gao F, Zhao K, Liao X, Li M, Rock DL, Luo S. Isolation and phylogenetic analysis of orf virus from the sheep herd outbreak in Northeast China. BMC Vet Res. 2012;8(1):229.

17. Chan KW, Lin JW, Lee SH, Liao CJ, Tsai MC, Hsu WL, Wong ML, Shih HC. Identification and phylogenetic analysis of orf virus from goats in Taiwan. Virus Genes. 2007;35(3):705-12. https://doi.org/10.1007/s11262-007-0144-6.

18. Amann R, Rohde J, Wulle U, Conlee D, Raue R, Martinon O, Rziha HJ. A new rabies vaccine based on a recombinant ORF virus (parapoxvirus) expressing the rabies virus glycoprotein. J Virol. 2013;87(3):1618-30.

19. Chan KW, Yang CH, Lin JW, Wang HC, Lin FY, Kuo ST, Wong ML, Hsu WL. Phylogenetic analysis of parapoxviruses and the C-terminal heterogeneity of viral ATPase proteins. Gene. 2009;432(1-2):44-53. https://doi.org/10.1016/j. gene.2008.10.029.

20. Jeffery et al., (2010): https://agrilifecdn.tamu.edu/sanangelo/files/2011/11/ Evaluation-of-homologous-and-heterologous-protection-induced-by-avirulent-field-strain-of-orf-virus-and-an-orf-vaccine-in-goats.pdf.

21. De La Concha-Bermejillo A, Guo J, Zhang Z, Waldron D. Severe persistent orf in young goats. J Vet Diagn Investig. 2003;15(5):423-31.

22. Kumar R, Trivedi RN, Bhatt P, Khan SUH, Khurana KS, Tiwari R, Karthik K, Malik YS, Dhama K, Chandra R. Contagious pustular dermatitis (Orf disease) - epidemiology, diagnosis, control and public health concerns. Adv Anim Vet Sci. 2015;3(12):649-76. https://doi.org/10.1056/NEJMra1112830.

23. Hota A, Biswal S, Sahoo N, Venkatesan G, Arya S, Kumar A, Ramakrishnan MA, Pandey AB, Rout M. Seroprevalence of Capripoxvirus infection in sheep and goats among different agro-climatic zones of Odisha, India. Vet World. 2018;11(1):66

24. Onyango J, Mata F, McCormick W, Chapman S. Prevalence, risk factors and vaccination efficacy of contagious ovine ecthyma (orf) in England. Vet Rec. 2014;175(13):326. https://doi.org/10.1136/vr.102353.

25. Alim ABNM. Contagious ecthyma in Malaysia. Technical Report No. 9. Kuala Lumpur: Jabatan Perkhidmatan Haiwan; 1990.

26. Jesse FFA, Latif SN, Abba Y, Hambali IU, Bitrus AA, Peter ID, Haron AW, Bala JA, Balakrishnan KN, Abdullah AA, Lila MA. Seroprevalence of orf infection based on IgM antibody detection in sheep and goats from selected small ruminant farms in Malaysia. Comp Clin Pathol. 2018a;27(2):499-503. https:// doi.org/10.1007/s00580-017-2619-8.

27. Bala JA, Balakrishnan KN, Abdullah AA, Yi LC, Bitrus AA, Abba Y, Aliyu IA, Peter ID, Hambali IU, Mohamed RB, Jesse FFA, Haron AW, Noordin MM, Mohd-Lila
MA. Sero-epidemiology of contagious ecthyma based on detection of lgG antibody in selected sheep and goats farms in Malaysia. Adv Anim Vet Sci. 2018b;6(5):219-26. https://doi.org/10.17582/journal.aavs/2018/6.5.219.226.

28. Gökce HI, Genc O, Gökce G. Sero-prevalence of contagious ecthyma in lambs and humans in Kars, Turkey. Turk J Vet Anim Sci. 2005;29(1):95-101.

29. Bala JA, Balakrishnan KN, Abdullah AA, Kimmy T, Abba Y, Bin Mohamed R, Jesse FFA, Haron AW, Noordin MM, Bitrus AA, Hambali IU.

Dermatopathology of Orf Virus (Malaysian Isolates) in mice experimentally inoculated at different sites with and without Dexamethasone Administration. J Pathog. 2018c;2018:9207576 12 pages.

30. Yeshwas F, Almaz H, Sisay G. Confirmatory diagnosis of contagious ecthyma (Orf) by polymerase chain reaction at Adet sheep research sub-center, Ethiopia: a case report. J Vet Med Anim Health. 2014;6(July):187-91. https:// doi.org/10.5897/JVMAH2014.0289.

31. Mazur C, Ferreira II, Filho FB, Galler R. Molecular characterization of Brazilian isolates of orf virus. Vet Microbiol. 2000;73:253-9. https://doi.org/10.1016/S03 78-1135(99)00151-0.

32. Jesse FFA, Hambali IU, Abba Y, Lin CC, Chung ELT, Bitrus AA, Mohd Lila MA. Effect of dexamethasone administration on the pathogenicity and lesion severity in rats experimentally inoculated with Orf virus (Malaysian isolates). Comp Clin Pathol. 2018b:1-10. https://doi.org/10.1007/s00580-018-2726-1.

33. Balakrishnan S, Venkataramanan R, Ramesh A, Roy P. Contagious ecthyma outbreak among goats at Nilgiri hills. Indian J Anim Res. 2017. https://doi. org/10.18805/ijar.10277.

34. Housawi FMT, Elzein EA, Al Afaleg Al, Amin MM. Sero-surveillance for Orf antibodies in sheep and goats in Saudi Arabia employing the ELISA technique. J Comp Pathol. 1992;106(2):153-8.

35. Nandi S, De UK, Chowdhury S. Current status of contagious ecthyma or orf disease in goat and sheep-a global perspective. Small Rumin Res. 2011; 96(2-3):73-82. https://doi.org/10.1016/j.smallrumres.2010.11.018.

36. Bora M, Bora DP, Barman NN, Borah B, Das S. Seroprevalence of contagious ecthyma in goats of Assam: an analysis by indirect enzyme-linked immunosorbent assay. Vet World. 2016, 1028;9(9). https://doi.org/10.14202/ vetworld.2016.1028-1033

37. Chi X, Zeng X, Hao W, Li M, Li W, Huang X, Wang S, Luo S. Heterogeneity among Orf virus isolates from goats in Fujian Province, southern China. PLoS One. 2013;8(10). https://doi.org/10.1371/journal.pone.0066958.

38. Orgeur $\mathrm{P}$, Mimouni $\mathrm{P}$, Signoret JP. The influence of rearing conditions on the social relationships of young male goats ( Capra hircus). Appl Anim Behav Sci. 1990;27:105-13. https://doi.org/10.1016/0168-1591(90)90010-B Elsevier Science Publishers B. V.

39. McElroy MC, Bassett HF. The development of oral lesions in lambs naturally infected with orf virus. Vet J. 2007;174(3):663-4. https://doi.org/10.1016/j. tvjl.2006.10.024.

40. Chavez-Alvarez S, Barbosa-Moreno L, Villarreal-Martinez A, Vazquez-Martinez OT, Ocampo-Candiani J. Dermoscopy of contagious ecthyma (orf nodule). J Am Acad Dermatol. 2016;74(5):e95-6. https://doi.org/10.1016/j.jaad.2015.10.047.

41. Delhon G, Tulman ER, Afonso CL, Lu Z, De A, Lehmkuhl HD, Piccone ME, Kutish GF. Genomes of the Parapoxviruses Orf Virus and Bovine Papular Stomatitis Virus Genomes of the Parapoxviruses Orf Virus and Bovine Papular Stomatitis Virus. 2004;78(1):168-77. https://doi.org/10.1128/JVI.78.1.168.

42. Spyrou V, Valiakos G. Orf virus infection in sheep or goats. Vet Microbiol. 2015:181(1-2):178-82. https://doi.org/10.1016/j.vetmic.2015.08.010.

43. Abdullah FFJ, Rofie AMB, Tijjani A, Chung ELT, Mohammed K, Sadiq MA, Saharee AA, Abba Y. Survey of goat farmers' compliance on proper herd health program practices. Int J Livest Res. 2015b;5(11):8-14. https://doi.org/1 0.5455/ijlr.20151103105812.

44. Mobini S. Herd ealth Management practices for goat production. In Proc. 14th Ann. Langston: Goat Field Day. Langston: Langston Universit; 1999. p. 13-22. http://www.luresext.edu/sites/default/files/1999\%20Field\%20Day.pdf.

45. Zamri-Saad M, Al-Ajeeli KS, Ibrahim A. A severe outbreak of Orf involving the buccal cavity of goats. Trop Anim Health Prod. 1992;24(3):177-8.

46. Thurman RJ, Fitch RW. Contagious Ecthyma. N Engl J Med. 2015;372(8):e12.

47. Azmi MLM, Field HJ, Rixon F, McLauchlan J. Protective immune Reponses induced by non-infectious L-particles of equine herpesvirus Type-1. J Microbiol. 2002:40(1):11-9.

48. Musser JM, Taylor CA, Guo J, Tizard IR, Walker JW. Development of a contagious ecthyma vaccine for goats. Am J Vet Res. 2008;69(10):1366-70.

49. Musser JM, Waldron DF, Taylor CA. Evaluation of homologous and heterologous protection induced by a virulent field strain of Orf virus and an Orf vaccine in goats. Am J Vet Res. 2012;73(1):86-90. 
50. Zhao K, He W, Gao W, Lu H, Han T, Li J, Zhang X, Zhang B, Wang G, Su G. Orf virus DNA vaccines expressing ORFV 011 and ORFV 059 chimeric protein enhances immunogenicity. Virol J. 2011;8(1):562. https://doi.org/1 $0.1186 / 1743-422 X-8-562$

51. Zhao K, Song D, He W, Lu H, Zhang B, Li C, Chen K, Gao F. Identification and phylogenetic analysis of an Orf virus isolated from an outbreak in sheep in the Jilin province of China. Vet Microbiol. 2010;142(3-4):408-15. https://doi.org/10.1016/j.vetmic.2009.10.006.

52. Lewis C. Update on orf. In Practice. 1996;18:376-81. https://doi.org/10.1136/ inpract.18.8.376.

53. Scagliarini A, Piovesana S, Turrini F, Savini F, Sithole F, Mccrindle CM. Orf in South Africa: endemic but neglected. Onderstepoort J Vet Res. 2012;79:1-8 http://hdl.handle.net/10520/EJC129087.

54. Hosamani M, Scagliarini A, Bhanuprakash V, Mclnnes CJ, Singh RK. Orf: an update on current research and future perspectives. Expert Rev Anti-Infect Ther. 2009;7(7):879-93. https://doi.org/10.1586/eri.09.64

55. Inoshima Y, Yamamoto $Y$, Takahashi $T$, Shino M, Katsumi A, Shimizu S, Sentsui $H$. Serological survey of parapoxvirus infection in wild ruminants in Japan in 1996-9. Epidemiol Infect. 2001;126(1):153-6. https://doi.org/10.101 7/S0950268801005131.

56. Steven J, Jeremy P. Herd health program for meat goats. In livestock health series, agriculture and natural resources, publication of the division of agriculture, research and extension, University of Ankansas system. 2015 https://www.uaex.edu/publications/PDF/FSA-3097.pdf. Accessed 26 July 2015.

57. Doye D. The use of electronic technology in teaching farm record keeping. Am J Agric Econ. 2004:86(3):762-6. https://doi.org/10.1111/j.0002-9092.2004.00621.x.

58. Animal Health Australia. Canberra: Animal Health in Australia 2009; 2010. p. 49-56. https://animalhealthaustralia.com.au/wp-content/uploads/2015/12/ AHIA-2009.pdf. Accessed 26 July 2015

59. Jensen $\mathrm{KL}$, English BC, Menard RJ. Livestock farmers' use of animal or herd health information sources. J Ext. 2009;47(1):1FEA7 Available at:http://www. joe.org/joe/2009february/a7.php.

60. Maclnnes H, Zhou Y, Gouveia K, Cromwell J, Lowery K, Layton RC, Zubelewicz M, Sampath R, Hofstadler S, Liu Y, Cheng YS. Transmission of aerosolized seasonal H1N1 influenza a to ferrets. PloS one. 2011;6(9):e24448. https://doi.org/10.1371/journal.pone.0024448.

61. Koopman G, Mooij P, Dekking L, Mortier D, Nieuwenhuis I, van Heteren M, Kuipers H, Remarque EJ, Radošević K, Bogers WM. Correlation between virus replication and antibody responses in macaques following infection with pandemic influenza a virus. J Virol, JVI-02757. 2015. https://doi.org/10.1128/ JVI.02757-15.

62. Inoshima Y, Morooka A, Sentsui H. Detection and diagnosis of parapoxvirus by the polymerase chain reaction. J Virol Methods. 2000;84(2):201-8. https:// www.sciencedirect.com/science/article/pii/S0166093499001445?via\%3Dihub.

63. Inoshima Y, Takasu M, Ishiguro N. Establishment of an on-site diagnostic procedure for detection of orf virus from oral lesions of Japanese serows (Capricornis crispus) by loop-mediated isothermal amplification. J Vet Med Sci. 2016;78(12):1841-5. https://doi.org/10.1292/jvms.16-0268.

64. Chaudhri G, Panchanathan V, Bluethmann H, Karupiah G. Obligatory requirement for antibody in recovery from a primary poxvirus infection. J Virol. 2006;80(13):6339-44. https://doi.org/10.1128/JVI.00116-06.

65. Jegaskanda S, Weinfurter JT, Friedrich TC, Kent SJ. Antibody-dependent cellular cytotoxicity (ADCC) is associated with control of pandemic H1N1 influenza virus infection of macaques. J Virol. 2013:JVI-03030. https://doi. org/10.1128/JVI.03030-12.

66. Panchanathan $\mathrm{V}$, Chaudhri G, Karupiah G. Protective immunity against secondary poxvirus infection is dependent on antibody but not on CD4 or CD8 T-cell function. J Virol. 2006;80(13):6333-8. https://doi.org/10.1128/JVI.00115-06.

67. Panchanathan V, Chaudhri G, Karupiah G. Correlates of protective immunity in poxvirus infection: where does antibody stand? Immunol Cell Biol. 2008; 86(1):80-6. https://doi.org/10.1038/sj.icb.7100118.

68. Edghill-Smith $Y$, Golding H, Manischewitz J, King LR, Scott D, Bray M, Nalca A, Hooper JW, Whitehouse CA, Schmitz JE, Reimann KA. Smallpox vaccineinduced antibodies are necessary and sufficient for protection against monkeypox virus. Nat Med. 2005;11(7):740. https://doi.org/10.1038/nm1261.

69. Nollens HH, Gulland FM, Hernandez JA, Condit RC, Klein PA, Walsh MT, Jacobson ER. Seroepidemiology of parapoxvirus infections in captive and free-ranging California Sea lions Zalophus californianus. Dis Aquat Org. 2006; 69(2-3):153-61. https://doi.org/10.3354/dao069153.
70. Haig DM. Orf virus infection and host immunity. Curr Opin Infect Dis. 2006; 19(2):127-31.

71. Bergqvist C, Kurban M, Abbas O. Orf virus infection. Rev Med Virol. 2017; 27(4):1-9. https://doi.org/10.1002/rmv.1932.

72. Kitchen M, Müller H, Zobl A, Windisch A, Romani N, Huemer H. Orf virus infection in a hunter in Western Austria, presumably transmitted by game. Acta Derm Venereol. 2014;94(2):212-4. https://doi.org/10.2340/ 00015555-1643.

73. Kottaridi C, Nomikou K, Teodori L, Savini G, Lelli R, Markoulatos P, Mangana O. Phylogenetic correlation of Greek and Italian orf virus isolates based on VIR gene. Vet Microbiol. 2006;116(4):310-6. https://doi.org/10.1016/j.vetmic.2 006.04.020.

74. Lojkic I, Cac Z, Beck A, Bedekovic T, Cvetnic Z, Sostaric B. Phylogenetic analysis of Croatian orf viruses isolated from sheep and goats. Virol J. 2010;7: 1-7. https://doi.org/10.1186/1743-422X-7-314.

75. Maganga GD, Relmy A, Bakkali-Kassimi L, Ngoubangoye B, Tsoumbou T, Bouchier C, Berthet N. Molecular characterization of Orf virus in goats in Gabon, Central Africa. Virol J. 2016;13(1):1-5. https://doi.org/10.1186/s12985016-0535-1.

76. Arya R, Antonisamy B, Kumar S. Sample size estimation in prevalence studies. Indian J Pediatr. 2012. https://doi.org/10.1007/s12098-012-0763-3.

77. Bala JA, Kawo AH, Mukhtar MD, Sarki A, Magaji N, Aliyu IA, Sani MN. Prevalence of hepatitis $C$ virus infection among blood donors in some selected hospitals in Kano, Nigeria. (IRJM) (ISSN: 2141-5463). Int Res J Microbiol. 2012;3(6):217-22.

78. Balamurugan V, Singh RP, Saravanan P, Sen A, Sarkar J, Sahay B, Rasool TJ, Singh RK. Development of an indirect ELISA for the detection of antibodies against Peste-des-petits-ruminants virus in small ruminants. Vet Res Commun. 2007;31(3):355-64.

79. Loh HS, Mohd-Azmi ML. Development of a quantitative real-time RT-PCR for kinetic analysis of immediate-early transcripts of rat cytomegalovirus. Acta Virol. 2009:53(4):261-9 http://www.elis.sk/download_file.php?product_id= 1776\&session_id=cufekitil8/necdkjhp3vkbr02.

80. Tam YJ, Allaudin ZN, Lila MAM, Bahaman AR, Tan JS, Rezaei MA. Enhanced cell disruption strategy in the release of recombinant hepatitis B surface antigen from Pichia pastoris using response surface methodology. BMC Biotechnol. 2012;12, art. no.(70). https://doi.org/10.1186/1472-6750-12-70.

81. Guo J, Zhang Z, Edwards JF, Ermel RW, Taylor C, De La Concha-Bermejillo A. Characterization of a north American orf virus isolated from a goat with persistent, proliferative dermatitis. Virus Res. 2003;93(2):169-79. https://doi. org/10.1016/S0168-1702(03)00095-9.

82. Babiuk S, Wallace DB, Smith SJ, Bowden TR, Dalman B, Parkyn G, Copps J, Boyle DB. Detection of antibodies against capripoxviruses using an inactivated sheeppox virus ELISA. Transbound Emerg Dis. 2009;56(4):132-41.

83. Bhanuprakash V, Hosamani M, Juneja S, Kumar N, Singh RK. Detection of goat pox antibodies: comparative efficacy of indirect ELISA and counterimmunoelectrophoresis. J Appl Anim Res. 2006;30(2):177-80

84. Niang AB. Principles of validation of diagnostic assays for infectious diseases. Manual of diagnostic tests and vaccines for terrestrial animals, vol. 1; 2004. p. 21-9.

85. Azmi M, Field HJ. Interactions between equine herpesvirus type 1 and equine herpesvirus type 4: T cell responses in a murine infection model. J Gen Virol. 1993;74(11):2339-45. https://doi.org/10.1099/0022-1317-74-11-2339.

86. Vakhshiteh F, Allaudin ZN, Mohd-Lila MAB, Hani H. Size-related assessment on viability and insulin secretion of caprine islets in vitro. Xenotransplantation. 2013;20(2):82-8. https://doi.org/10.1111/xen.12023.

\section{Publisher's Note}

Springer Nature remains neutral with regard to jurisdictional claims in published maps and institutional affiliations. 